\title{
PERANCANGAN ALAT BANTU KERJA PENGELASAN SUPPORT DENGAN REKAYASA NILAI DAN ERGONOMI (STUDI KASUS: PT. PRIMAKARYA JAYA SEJAHTERA)
}

\author{
Khusnul Ma'arif, Deny Andesta dan Said Salim Dahda \\ Program Studi Teknik Industri \\ Universitas Muhammadiyah Gresik \\ Email :khusnul.starlight@gmail.com
}

\begin{abstract}
ABSTRAK
$\mathrm{P}$ . Primakarya Jaya Sejahtera merupakan perusahaan yang bergerak dalam bidang jasa pemeliharaan, perawatan, overhaul, steam turbin, compressor, blower, pompa air.Aktifitas dalam pengelasan yang sering dilakukan yaitu pembuatan penopang (support) yangdigunakan untuk menahan line pipe dan Support Pump. Support yang diproduksi perusahaan memiliki dimensi yang bervariasi sesuai dengan permintaan dan bermacam bentuk,dengan menggunakan mesin las listrik. Setiap operator melakukan aktivitas pengelasan dengan fasilitas bantu yang ada sejajar dengan lantai, sehingga mengharuskan operator cenderung menghasilkan posisi duduk jongkok, punggung membungkuk, mengabaikan prinsip-prinsip kerja ergonomis, yang mengakibatkan ketidaknyamanan kerja(kelelahan). Keadaan ini beresiko menimbulkan kelelahan. Penelitian ini bertujuan untuk mendesain alat bantu pengelasan support dengan harapan untuk memperbaiki postur pekerja operator las saat melakukan aktivitas pengelasan melalui konsep Rekayasa Nilai, dengan penerapan prinsip ergonomi terutama dalam hal penentuan dimensi ukuran-ukurannya yang akan mengaplikasikan data anhtropometri yang relevan.

Penelitian ini diawali dengan mengidentifikasi fasilitas kerja pengelasan, posisi postur tubuh pekerja, ketidaknyamanan operator (mengenai keluhan dan harapan operator untuk sikap kerja melalui analisis kuisioner nordic body map). Kemudian hasilnya diterjemahkan menjadi konsep perancangan alat bantu pengelasan, yaitu berupa meja dudukan benda kerja pengelasan support. Tahapan kedua adalah memunculkan alternatif- alternatif alat bantu. Tahapan ketiga adalah melakukan analisis terhadap alternatif- alternatif alat bantu yang muncul. Tahapan keempat dilakukan analisa biaya dan perhitungan value dengan menggunakan nilai performansi diperoleh dari hasil tahapan ketiga. Dan tahapan kelima akan dipersentasikan alternatif terbaik yang terpilih dengan nilai (value) tertinggi yaitu 1,31, serta akan disajikan laporan lengkap hasil analisa. Dari hasil penggunaan alat bantu ini terdapat perbaikan postur kerja operator pada saat melakukan aktivitas pengelasan, sehingga operator berada dalam kondisi yang aman.
\end{abstract}

Kata Kunci: Alat Bantu Las, Ergonomi-Anthropometri, Rekayasa Nilai, Diagram FAST, AHP-Expert Choice

\section{PENDAHULUAN}

PT. Primakarya Jaya Sejahtera merupakan perusahaan yang bergerak dalam bidang jasa pemeliharaan, perawatan, overhaul, steam turbin, compressor, blower, pompa air. Perusahaanini berlokasi di Jalan Raya Bengawan Solo No. 16 Randuagung Gresik. Perusahaan ini merupakan mitra kerja yang bekerja sama dengan departemen mekanik di PT. Petro Jordan Abadi dan juga mempunyai bengkel yang berlokasi di area PT. Petro Jordan Abadi.

Aktivitas di bengkel PT. Primakarya Jaya Sejahtera selain dibidang jasa Maintenance. di bengkel ini juga bergerak dibidang pengelasan logam seperti pembuatan support, pengelasan cover cashing pump dan line pipe pump yang bocor. Aktifitas dalam pengelasan yang sering dilakukan, yaitupenopang (support) yangdigunakan untuk menahan line pipe dan Support Pump. Support yang 
diproduksi perusahaan memiliki dimensi yang bervariasi sesuai dengan permintaan dan bermacam bentuk, diantaranya bentuk persegi, T, dan L, sesuai dengan kebutuhan line pipe pump atau support pump. Pembuatan Support menggunakan material berbahan logamseperti besi siku (angle), U-mp, dan canal.

Pada proses pembuatan supporttersebut, bengkel ini memiliki tiga stasiun kerja meliputi stasiun penggambaran dan pengukuran (pemotongan benda kerja sesuai pengukuran), stasiun pengelasan (perakitan), dan stasiun finishing(proses penghalusan/penggerindaan). Pada stasiun pengelasan dilakukan proses pengelasan dengan cara menyusun material (perakitan) plat-plat besi siku atau canal yang sudah terpotong disesuaikan menurut desain rancangan benda kerja yang sudah ditentukan. Pada saat perakitan membutuhkan 2 orang pekerja yaitu tukang las dan helper yang bisa menyebabkan helper terkena sinar radiasi pada saat dilakukan proses pegelasan. Proses pengelasan dilakukan di dasar permukaan yang tidak rata dan berpindah-pindah.

Penanganan material di bengkel PT. Primakarya Jaya Sejahtera sampai saat ini masih sering dilakukan secara manual dan belum ada fasilitas bantu pada pengerjaan pengelasan seperti dudukan landasan untuk pengerjaan pengelasan. Penanganan material secara manual melibatkan kemampuan fisik manusia dalam sebagian besar prosesnya. Aktivitas manual cenderung menekan pada bagian segmen tubuh untuk melakukan aktivitas kerja, sehingga aktivitas ini berpotensi menimbulkan gangguan fisik berupa keluhan musculoskeletal yaitu keluhan yang terjadi terhadap sistem untuk mendukung dan melindungi tubuh dan organ yang berbeda dan mempertahankan pergerakan tubuh.

Dalam mengetahui ketidaknyamanan yang dirasakan pada operator, dilakukan pengukuran terhadap seberapa besar resiko yang terjadi dengan posisi postur tubuh tersebut. Pada kasus ini pengukuran dilakukan dengan penyebaran kuesioner nordic body map (NBM) untuk mengetahui ketidaknyamanan dibeberapa segmen tubuh yang dirasakan operator terhadap posisi postur tubuh duduk jongkok tersebut

Hasil penilaian melalui kuesioner nordic body map (NBM) diketahui operator mengalami keluhan.Diketahui bahwa 5 operator mengalami keluhan di setiap segmen tubuhnya. Persentase tingkat keluhan menunjukkan ada empat segmen tubuh yang mengalami keluhan tertinggi dengan tingkat persentase lebih dari $50 \%$ yaitu segmen leher, punggung, pinggang, dan telapak kaki.

Dengan memperhatikan kondisi dan cara kerja yang tidak produktif yang berlangsung berulang kali seperti ini, maka peneliti akan mengembang- 
kan sebuah solusi alternatif berupa perancangan alat bantu pengelasan yang ergonomi. Perancangan alat bantu bertujuan untuk memperbaiki kinerja operator mesin las.Sebagai acuan dasar pengembangan sebuah solusi alternatif berupa perancangan alat bantu maka dilakukan kuisionertentang keluhan dan harapan dari para operator.

\section{TINJAUAN PUSTAKA}

\section{Ergonomi}

Istilah "ergonomi" berasal dari bahasa Latin yaitu ERGON (Kerja) dan NOMOS (Hukum alam) dan didefinisikan sebagai studi tentang aspek-aspek manusia dalam lingkungan kerjanya yang ditijau secara anatomi, fisiologi, psikologi, engineering, manajemen dan desain/perancangan (Nurmianto, 2005). Disiplin ergonomi secara khusus mempelajari keterbatasan dan kemampuan manusia dalam berinteraksi dengan teknologi dan produk-produk buatannya. Disiplin ini berangkat dari kenyataan bahwa manusia memiliki batas-batas kemampuan baik jangka pendek maupun jangka panjang, pada saat berhadapan dengan lingkungan sistem kerja yang berupa perangkat keras atau hardware (mesin, peralatan kerja) dan atau perangkat lunak atau software.

\section{Sikap Kerja Ergonomi}

Posisi tubuh dalam bekerja ditentukan oleh jenis pekerjaan yang dilakukan. Masing-masing po- sisi kerja mempunyai pengaruh yang berbeda-beda terhadap tubuh. Sikap tubuh dalam beraktivitas pekerjaan diakibatkan oleh hubungan antara dimensi kerja dengan variasi tempat kerja. Sikap tubuh pada saat melakukan setiap pekerjaan menentukan atau berpengaruh terhadap keberhasilan suatu pekerjaan.

\section{Desain dan Ergonomi}

Manusia dalam kehidupan sehari-harinya banyak menggunakan berbagai macam produk, mesin maupun peralatan kerja untuk memenuhi keperluannya. manusia merupakan komponen yang penting untuk setiap sistem operasional (sistem manusia-mesin) yang berfungsi untuk menghasilkan sebuah aktivitas kerja. Agar sistem tersebut dapat berfungsi baik, maka sub-sistem (komponen- komponen) pendukungnya haruslah dirancang “compatible" satu dengan yang sub-sistem mesin, tetapi juga menyangkut manusia yang berinteraksi dengan sub sistem mesin tersebut untuk membentuk sebuah sistem manusia-mesin (man- machine system). Oleh karena itu sangat mendasar sekali kalau seorang perancang mesin (produk) selalu mempertimbangkan manusia sebagai sub-sistem yang perlu diselaraskan dengan sub-sistem mesin (produk) yang layak dioperasikan nantinya.

Berkaitan dengan hal tersebut sudah semestinya seorang perancang mesin (produk) memperhatikan 
segala kelebihan maupun keterbatasan manusia dalam hal kepekaan inderawi (sensory), kecepatan dan ketepatan di dalam proses pengambilan keputusan, kemampuan penggunaan sistem gerakan otot, dimensi ukuran tubuh (anthropometri). Kemudian menggunakan semua informasi mengenai faktor manusia (human factors) ini sebagai acuan dalam menghasilkan rancangan mesin atau produk yang serasi, selaras dan seimbang dengan manusia yang mengoperasikannya (Wignjosoebroto, 1995).

Seorang perancang mesin (produk) memperhatikan segala kelebihan maupun keterbatasan manusia dalam hal kepekaan inderawi (sensory), kecepatan dan ketepatan dalam proses pengambilan keputusan, kemampuan penggunaan sistem gerakan otot, dimensi ukuran tubuh (anthropometri). Perancang produk harus dapat mengintegrasikan semua aspek manusiawi tersebut dalam karya rancanganya dalam sebuah konsep"Human Integrated Design".

Human Integrated Design (HID) dijelaskan berdasarkan 2 (dua) prinsip, yaitu seorang perancang produk harus menyadari benar bahwa faktor manusia menjadi kunci penentu sukses didalam operasionalisasi sistem manusia-mesin (produk), tidak peduli apakah sistem tersebut bersifat manual, mekanis (semi-automatic) atau otomatis penuh. Kemudian perancang produk harus menyadari bahwa setiap produk memerlukan informasi detail dari semua faktor yang terkait dalam setiap proses perancangan

Pertimbangan ergonomi dalam proses perancangan produk yang paling tampak nyata aplikasinya melalui pemanfaatan data anthropometri (ukuran tubuh) guna menetapkan dimensi ukuran geometris dari produk dan bentuk tertentu dari produk yang disesuaikan dengan ukuran maupun bentuk (feature) tubuh manusia pemakainya. Data anthropometri yang menyajikan informasi mengenai ukuran maupun bentuk dari berbagai anggota tubuh manusia yang dibedakan berdasarkan usia, jenis kelamin, suku bangsa (etnis), posisi tubuh pada saat bekerja yang diakomodasikan dalam penetapan dimensi ukuran produk yang dirancang.

\section{Anthropometri}

Anthropometri berasal dari "anthro" yang berarti manusia dan "metri" yang berarti ukuran. Anthropometri adalah studi tentang dimensi tubuh manusia. Secara definitif anthropometri dinyatakan sebagai suatu studi yang berkaitan dengan pengukuran dimensi tubuh manusia. Anthropometri merupakan ilmu yang menyelidiki manusia dari segi keadaan dan ciri-ciri fisiknya, seperti dimensi linier, volume, dan berat.

\section{Rekayasa Nilai}

Pengertian Analisa Nilai atau Rekayasa Nilai 
adalah suatu pendekatan yang terorganisasi dan kreatif yang bertujuan untuk mengadakan pengidentifikasian biaya yang tidak perlu. Biaya yang tidak perlu ini adalah biaya yang tidak memberikan kualitas, kegunaan, sesuatu yang menghidupkan, penampilan yang baik ataupun sifat yang diinginkan olehkonsumen(Barrie,1987).

Analisa Nilai dalam pengertian yang luas adalah sebuah prosedur disiplin yang diarahkan menuju penerimaan fungsi-fungsi yang diperlukan untuk mencapai biayaminimal, tanpa mengurangi mutu, kehandalan, kemampuan dan distribusi.

Sedangkan Rekayasa Nilai adalah pelaksanaan teknik-teknik Analisa Nilai dalam tahap perancangan utama dan pengembangan. Kontrol nilai adalah prosedur operasi yang digunakan oleh perusahaan untuk memastikan bahwa pertimbangan nilai akan terus diterapkan secara berkelanjutan.

\section{Tahapan-tahapan Rekayasa Nilai}

Menurut Hutabarat (1995) didalam Tinjauan Pustaka Rekayasa Nilai Tahapan-tahapan yang dilakukan dalam melakukan analisis Value Engineering ada 5 tahap, yaitu

1. Tahap Informasi.

2. Tahap Kreatif.

3. Tahap Analisis.

4. Tahap Pengembangan.

5. Tahap Persentasi.
Setiap tahapan mempunyai tujuan masing-masing dan mempunyai pertanyaan kunci yang harus dijawab sebagai alat bantu. Sedangkan kelima tahapan kerja analisa nilai harus melalui tahap demi tahap, namun tidak menutup kemungkinan jika sampai pada suatu tahap proses tersebut harus kembali ketahap sebelumnya.Pada gambar dibawah ini diilustrasikan hubungan antara satu tahap dengan tahap lainnya dalam proses kerja lima tahap

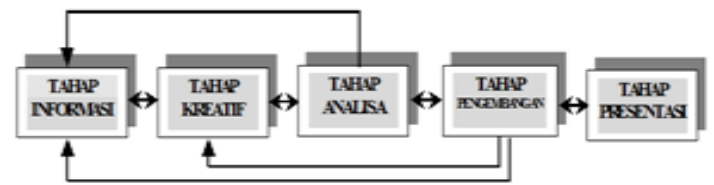

Gambar 1. Hubungan tahapan dalam rekayasa nilai

\section{Function Analysis System Technique}

Function Analysis System Technique (FAST) dilakukan untuk melihat identifikasi fungsi dasar dan fungsi pelengkap. Cara kerja diagram ini berawal dari penentuan fungsi utama dan bagaimana cara pencapainnya (how), dan akan dijelaskan mengenai hal tersebut dilakukan (why). Diagram ini juga melakukan pembagian antara lingkup design dan lingkup konstruksi untuk tercapainya analisa yang dibuat.

FAST yaitu suatu metoda untuk menganalisis, mengkoordinasi dan mencatat fungsi-fungsi dari sutu sistem secara terstruktur. Dengan menggunakan metoda ini nantinya akan dapat dibangun suatu diagram yang menggambarkan fungsi-fungsi 
setiap elemen dalam suatu proyek secara sistimatis dan dapat dicari hubungan antara masing-masing fungsi serta batasan lingkup permasalahan yang dikaji dengan menggunakan dua buah pertanyaan yaitu :Bagaimana (How), Mengapa (Why)

Dalam kasus ini diagram FAST dapat dilihat pada Gambar dibawah. Untuk lebih detailnya mengenai diagram FAST pembaca dapat melihat Value Standard and Body of Knowledge (2007).

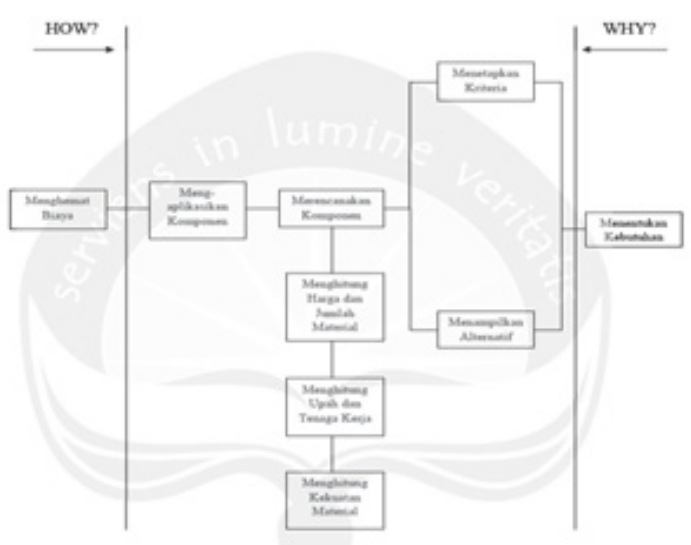

Gambar 2. Diagram FAST

\section{Analitycal Hierarchy Proces}

Metode AHP dikembangkan oleh Thomas L. Saaty, seorang ahli matematika. Metode ini adalah sebuah kerangka untuk mengambil keputusan dengann efektif atas persoalan yang kompleks dengann menyederhanakan dan mempercepat proses pengambilan keputusan dengann memecahkan persoalan tersebut kedalam bagian-bagiannya, menata bagian atau variabel dalam suatu susunan hirarki, memberi nilai numerik pada pertimbangan subjektif tentang pentingnya tiap variabel dan mensinte- sis berbagai pertimbangan ini untuk menetapkan variabel yang mana yang memiliki prioritas paling tinggi dan bertindak untuk mempengaruhi hasil pada situasi tersebut.

Menurut Saaty (2013), metode AHP membantu memecahkan persoalan yang kompleks dengann menstrukturkan suatu hirarki kriteria, pihak yang berkepentingan, hasil dan dengan menarik berbagai pertimbangan guna mengembangkan bobot atau prioritas. Metode ini juga menggabungkan kekuatan dari perasaan dan logika yang bersangkutan pada berbagai persoalan, lalu mensintesis berbagai pertimbangan yang beragam menjadi hasil yang cocok dengann perkiraan kita secara intuitif sebagaimana yang dipresentasikan pada pertimbangan yang telah dibuat.

\section{METODOLOGI PENELITIAN}

Pada bab ini diuraikan secara sistematis mengenai langkah-langkah yang dilakukan dalam penelitian. Langkah-langkah yang dilakukan dalam penelitian ditampilkan dalam gambar dibawah ini. 


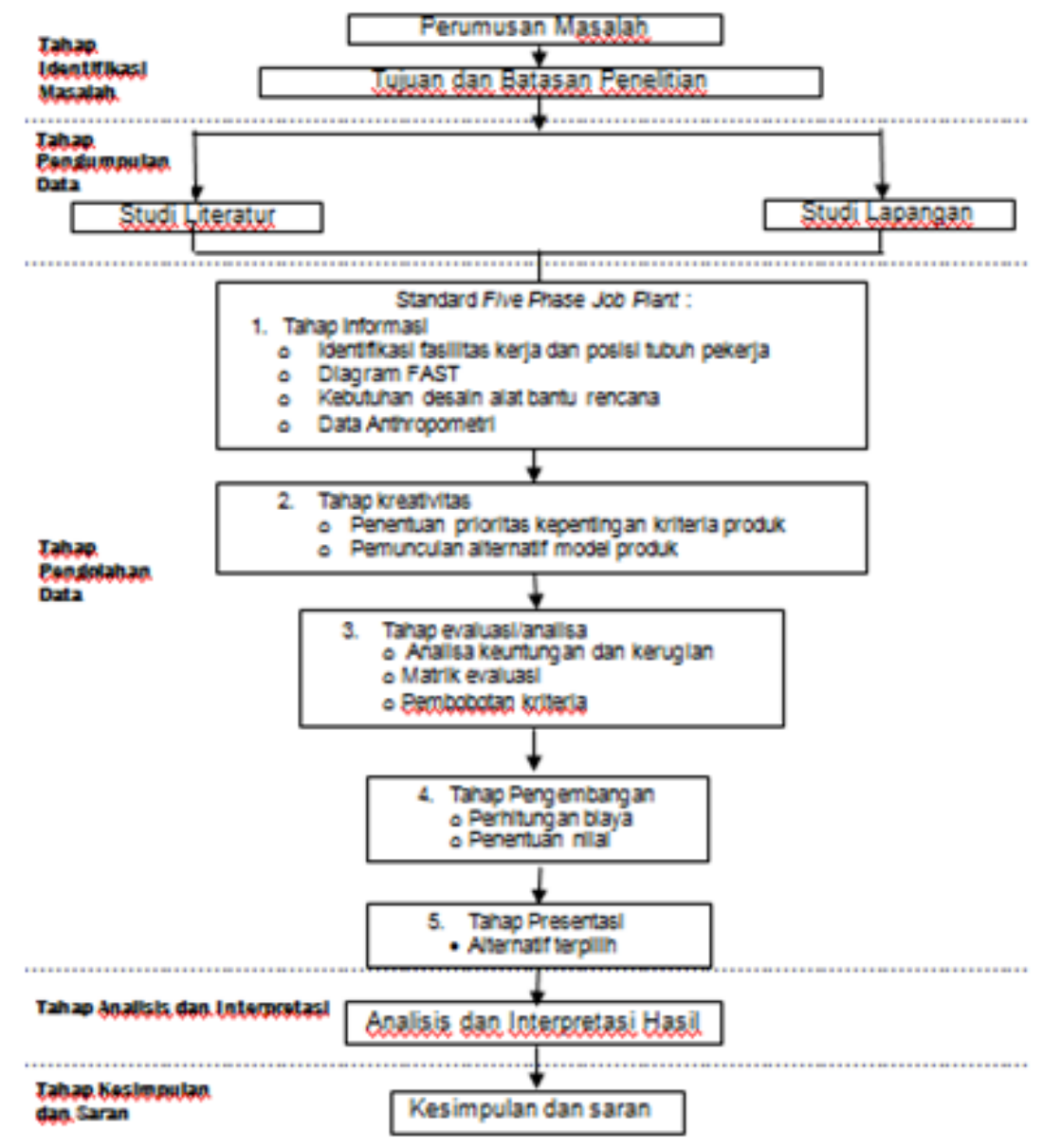

Gambar 3. Langkah-langkah penyelesaian penelitian

\section{HASIL DAN PEMBAHASAN}

Pada tahap pengumpulan dan pengolahan data yang di gunakan dalam penelitian kali ini adalah dengan mengunakan metode Five Phase Job Plant yang merupakan pengaplikasian dari langkahlangkah Rekayasa Nilai. Data telah didapatkan dari penelitian Ma'arif (2015).

\section{Tahap Informasi}

Metode Pengumpulan data yang di gunakan dalam penelitian kali ini adalah dengan mengunakan metode riset lapangan yang mana data yang diperoleh peneliti dengan melihat langsung yang sebenarnya terjadi dilapangan.

\section{Identifikasi Fasilitas Kerja dan Posisi Tubuh Pe-}

\section{kerja}

Langkah awal sebelum dilakukan perancangan alat bantu adalah mengidentifikasi fasilitas kerja yang menyebabkan kondisi dari posisi tubuh para pekerja tidak ergonomis. Identifikasi tersebut dapat dilihat pada gambar 3 . 


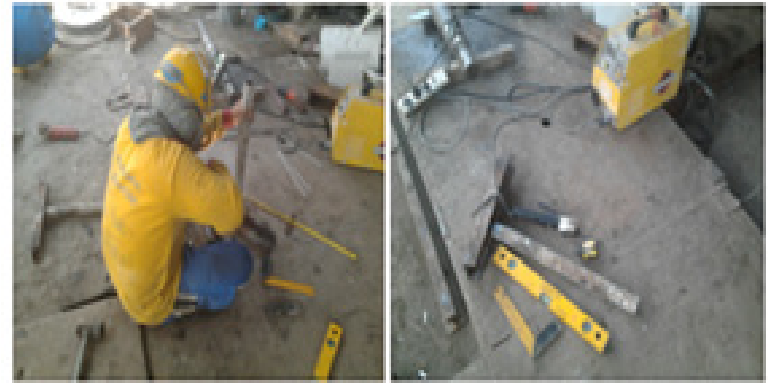

Gambar 4. Posisi pekerja dan Fasilitas bantu pengelasan support

Berdasarkan pada gambar 4.1 dan latar belakang masalah seperti yang telah diuraikan pada bab sebelumnya, maka pokok permasalahan yang dihadapi adalah bagaimana meningkatkan kinerja operator dengan melakukan modifikasi posisi dan tata cara kerja yang benar melalui pendekatan prinsip ergonomi.

Pengumpulan data dilakukan dengan cara membagikan kuisioner NBMkepada 5 orang operator las. Berdasarkan posisi postur tubuh pekerja yang tidak ergonomi dan hasil dari penyebaran kuisioner NBM, didapatkan keluhan dan harapan dari para operator. Untuk lebih jelasnya mengenai keluhan dan harapan dari para operator dapat dilihat pada tabel 1. dan 2 .

Tabel 1. Ketidaknyamanan / keluhan segmen tubuh pekerja

\begin{tabular}{|c|c|c|c|c|c|c|c|}
\hline \multirow{2}{*}{ No } & \multirow{2}{*}{ Bagian tubuh } & \multicolumn{5}{|c|}{ Operator ke } & \multirow{2}{*}{ Jumlah } \\
\cline { 3 - 7 } & & $\mathbf{1}$ & $\mathbf{2}$ & $\mathbf{3}$ & $\mathbf{4}$ & $\mathbf{5}$ & \\
\hline 1 & leher & v & & v & v & & 3 \\
\hline 2 & punggung & v & v & v & v & v & 5 \\
\hline 3 & pinggang & v & v & v & & v & 4 \\
\hline 4 & kaki & & v & v & v & v & 4 \\
\hline
\end{tabular}

Tabel 2. Harapan operator pada desain alat

\begin{tabular}{|c|c|c|c|}
\hline 8 & Harapan & Keburtuhan & Desain aht bestu \\
\hline 1 & 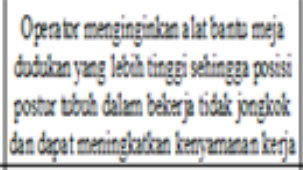 & 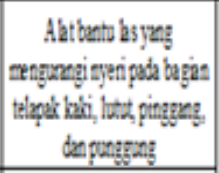 & \multirow{2}{*}{ 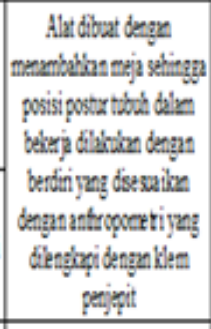 } \\
\hline & 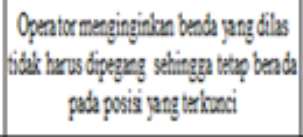 & 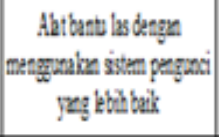 & \\
\hline & 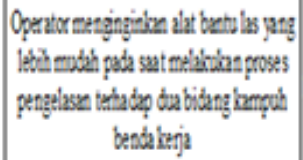 & 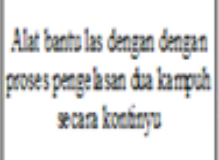 & 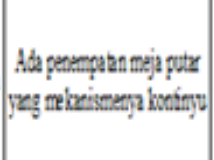 \\
\hline
\end{tabular}

Tabel 1. menjelaskan tentang keluhan-keluhan yang terjadi pada operator pada saat melakukan pengelasan. Sedangkan tabel 2. menjelaskan harapan dan kebutuhan desain alat bantu. Berdasarkan tabel 2. maka dilakukan perancangan / desain meja yang berfungsi untuk memudahkan operator untuk melakukan aktivitas pengelasan, sehingga operator bisa dengan aman dan nyaman dalam melakukan aktivitas pengelasan dan mengurangi keluhan. Berdasarkan harapan dan kebutuhan operator yang ditampilkan pada tabel 2., maka dikembangkan sejumlah ide maupun alternatif pemecahan masalah. Ide maupun alternatif-alternatif yang dikembangkan diharapkan dapat memenuhi kebutuhan dan mewakili konsep mekanisme perancangan alat bantu dudukan pengelasan support.

\section{Diagram FAST}

Diagram FAST disusun berdasarkan heraki fungsi, fungsi tingkat tinggi diletakkan sebelah kiri sedangkan fungsi tingkat rendah diletakkan 
disebelah kanan. Penysunan fungsi-fungsi dalam diagram FAST dilakukan dengan mengunakan dua buah pernyataan yaitu : bagaimana (how) dan mengapa (why).

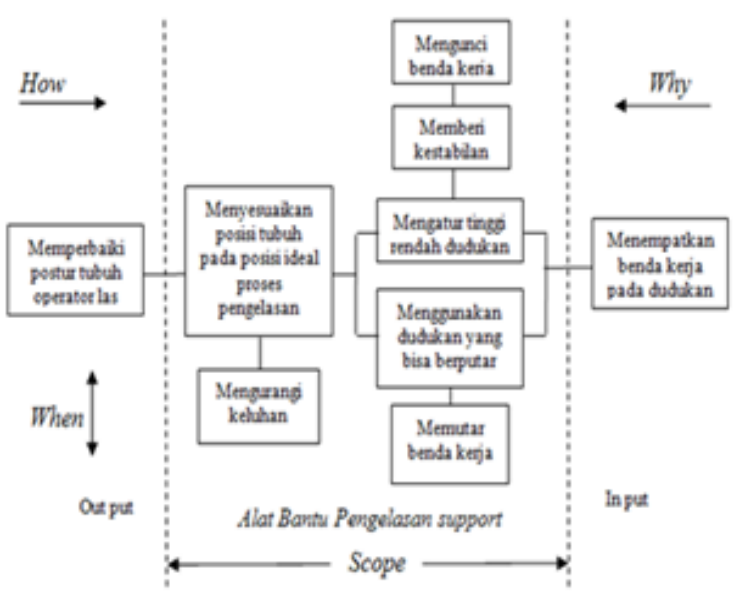

Gambar 5. Diagram FAST alat bantu pengelasan suppot

\section{Kebutuhan Desain Alat Bantu Rencana}

Untuk selanjutnya, peneliti melakukan penentuan kriteria-kriteria produk untuk kebutuhan desain alat bantu rencana untuk pengelasan support yang berdasarkan pada tabel 2. Kriteria-kriteria tersebut dijelaskan pada tabel 3 .

\section{Penggunaaan Data Anthropometri}

Penggunaan ukuran dimensi Anthrpometri pada alat digunakan sebagai penyempurna dalam pembuatan desain alternatif alat, agar dapat memenuhi keinginan dari fungsi alat yang akan dicapai peneliti. Dimana dalam pembuatan alat bantu dikatakan berhubungan dengan data anthropometri tersebut. Data anthropometri yang digunakan dalam perancangan alat bantu ialah: Tinggi mata dalam posisi berdiri tegak, tinggi siku dalam posisi berdiri tegak 90 (siku tegak lurus), jangkauan (posisi) tangan ke depan, dan panjang siku yang di ukur dari siku sampai dengan ujung jari-jari dalam posisi siku tegak lurus.

Tabel 3. Kriteria produk menurut keinginan pekerja las

\begin{tabular}{|c|c|c|}
\hline $\mathrm{No}_{0}$ & Keteria & Definisi \\
\hline 1. & $\begin{array}{l}\text { Kemampuan (menguci } \\
\text { bendikerja) }\end{array}$ & 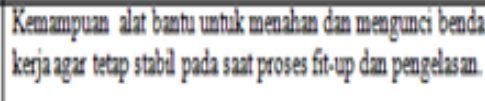 \\
\hline 2. & Keruddahan (sparepart) & 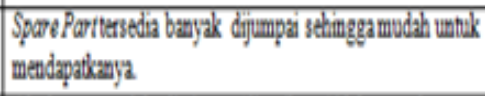 \\
\hline 3. & Portable(sowple) & 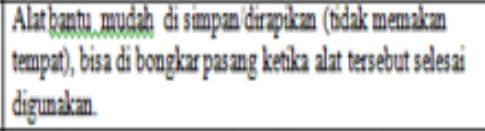 \\
\hline 4. & $\begin{array}{l}\text { Kenyamentan (Satt } \\
\text { Peogopersizan) }\end{array}$ & 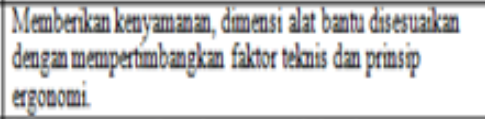 \\
\hline 5 & Adurable & 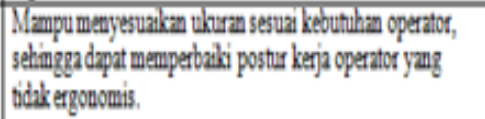 \\
\hline
\end{tabular}

\section{Tahap Kreatif}

Pada tahap kereatif ini peneliti dituntut untuk memunculkan alternatif desain yang terbaik guna untuk mendapatkan alternatif desain alat bantu dengan performans yang tinggi.

Penentuan Prioritas Tingkat Kepentingan Kri-

\section{teria Produk}

Dalam penentuan tingkat kriteria ini, peneliti melakukan pengumpulan data dengan melakukan survey mengunakan kuisioner yang di sebarkan kepada responden yang telah di pilih.Dari hasil kuisioner yang disebarkan, maka diperoleh tingkat kepentingan dari kriteria yang akan dipakai dalam perhitungan matrik evaluasi pada alternatif awal dan alternatif pilihan. Adapun urutan/rangking- 
perioritas tingkat kepentingan tersebut adalah ;

1. Kenyamanan, 2. Kemampuan, 3. Adjustable, 4. Portable(simple), 5. Kemudahan Spare part.

\section{Pemunculan Alternatif-alternatif Produk}

Berdasarkan dari penelitian alternatif awal dan berbagai macam pertimbangan maka didapatkan beberapa alternatif, adapun alternatif yang di munculkan antara lain :
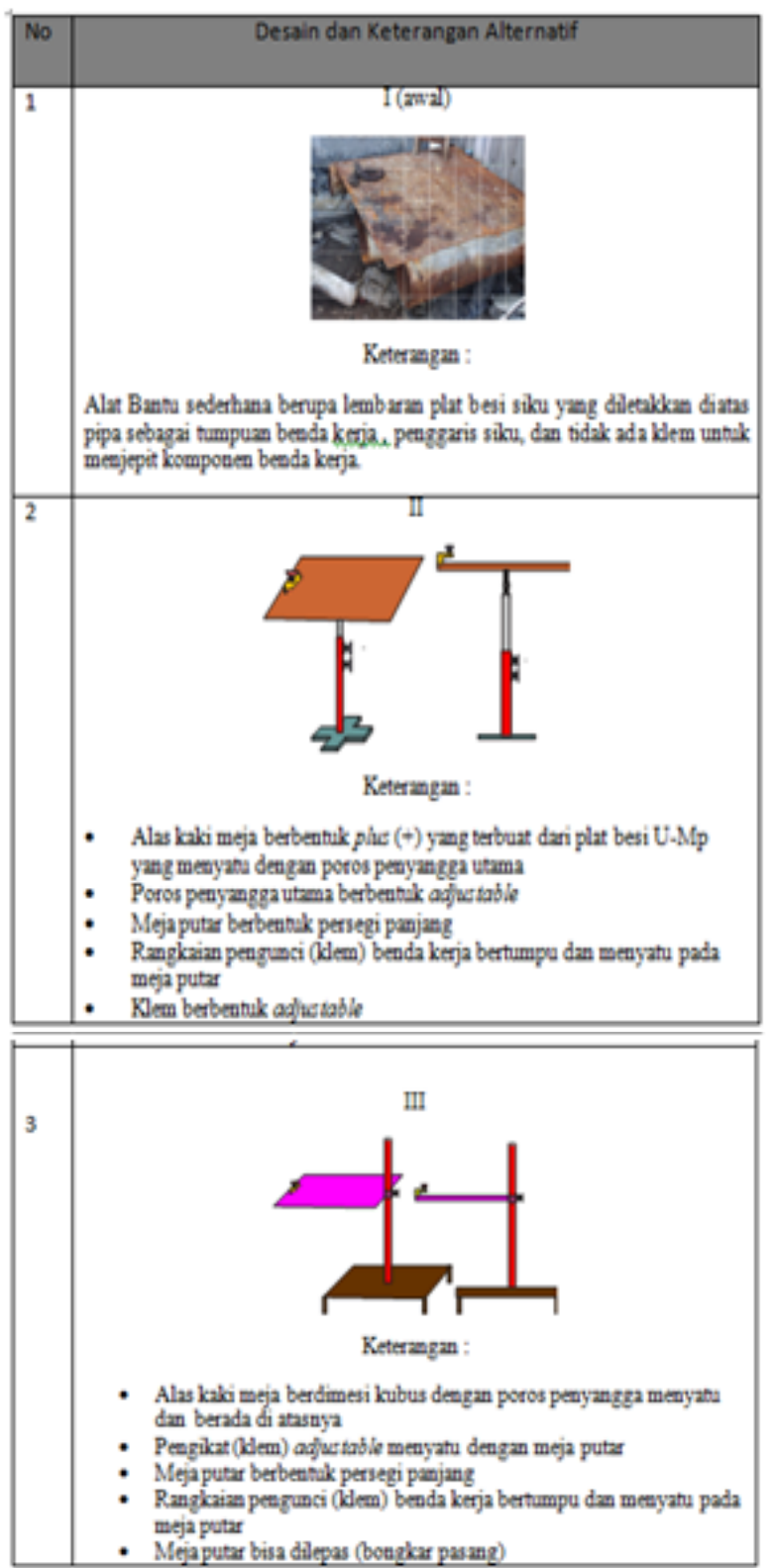

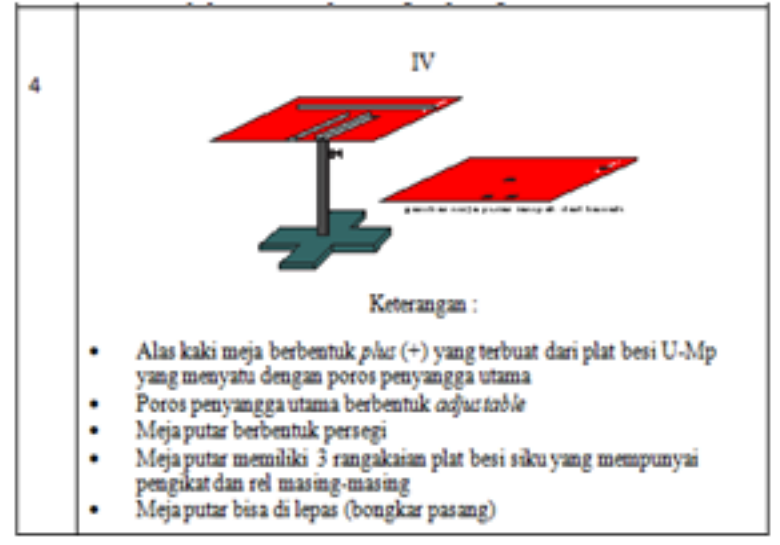

Gambar 5. Alternatif-alternatif Produk

\section{Tahap Analisa}

Setelah melalui tahap kreatif, selanjutnya dilakukan Tahap Analisa atau tahap evaluasi. Tahap Analisa ini dilakukan dengan berberapa analisa antara lain: (1) Analisa keuntungan dan kerugian pada alternative. (2) Perhitungan penilaian keteria yang dibangun dengan matrik kelayakan (3) Analisa pembobotan pada kriteria (4) Perhitungan performansi dengan matrik evaluasi terhadap alternatif yang terpilih.

\section{Tahap Pengembangan}

Pada tahap pengembangan ini akan dilakukan 2 perhitungan yaitu analisa biaya dan perhitungan Value dengan mengunakan nilai performansi yang diperoleh dari hasil analisa dengan mengunakan matrik evaluasi

\section{Penentuan Prioritas Tingkat Kepentingan Kri-}

\section{teria Produk}

Dalam perhitungan biaya ini akan dijelaskan mengenai biaya komponen dari alternatif yang ter- 
pilih. Perhitungan biaya dilakukan pada 3 alternatif dan 1 alternatif awal. Komponen biaya yang dipertimbangkan meliputi : biaya material atau bahan, biaya pendukung yang dikeluarkan dalam pembuatan, biaya pembuatan yang dikeluarkan dalam proses pembuatan alternatif juga termasuk tenaga kerja yang terlibat. Biaya dari setiap alternatif terpilih dan alternatif awal adalah sebagai berikut :

Tabel 4. Biaya pembuatan tiap alternatif alat bantu

\begin{tabular}{|c|c|c|}
\hline \multirow{2}{*}{ NO } & \multicolumn{2}{|c|}{ Biaya alternatif } \\
\cline { 2 - 3 } & Alternatif & Biaya (Rp) \\
\hline 1 & I & Rp 156.700 \\
\hline 2 & II & Rp 291.200 \\
\hline 3 & III & Rp 220.900 \\
\hline 4 & IV & Rp 332.300 \\
\hline
\end{tabular}

\section{Penentuan Nilai}

Berdasarkan hasil analisa pada tahap sebelumnya diperoleh performansi dari biaya pembuatan alat bantu pengelasan, maka nilai tersebut akan dibandingkan sehingga diperoleh suatu nilai (value) sebagai bahan pertimbangan dalam pemilihan alternatif. Perhitungan akan ditentukan dengan mengunakan : Rumus ; V $=\mathrm{P} / \mathrm{V}$, Dimana : $\mathrm{V}=$ Nilai (value), $\mathrm{P}=$ Performansi, $\mathrm{C}=$ Biaya

Perhitungan nilai Value Alternatif I (Awal)

$$
V_{n}=\frac{8.705,56 \times 18}{156.700}=1
$$

Perhitungan nilai Value Alternatif II

$$
\mathbf{V}=\frac{8.705,56 \times 33}{291.200}=0,99
$$

\section{Perhitungan nilai Value Alternatif III}

$$
\mathbf{V n}=\frac{8.705,56 \times 31}{220.900}=1,22
$$

\section{Perhitungan nilai Value Alternatif IV}

$$
\mathbf{V n}=\frac{8.705,56 \times 50}{332.300}=1,31
$$

Dengan menggunakan perumusan diatas, maka dapat diperoleh nilai untuk alternatif terpilih dan alternatif yang lain.

\section{Tahap Presentasi}

Tahap akhir dari 5 tahap rencana kerja adalah tahap presentasi yang merupakan tahap yang menjelaskan dari alternatif yang terbaik yang dipilih dari perhitungan nilai performansi pada masingmasing alat bantu dapat diperoleh nilai (value) yang dapat menentukan alat bantu terbaik yang akan dipresentasikan. Berdasarkan hasil perhitungan nilai (value), maka dapat diketahui selisih nilai dari ke tiga alternatif terpilih dengan alternatif awal. Bahwasanya pada alternatif IV (empat) memiliki nilai (value) lebih tinggi dari alternatif awal dan alternatif yang lain. Hal ini di jelaskan selengkapnya pada tabel 4.15 sebagai berikut :

Tabel 5. Value tiap alternatif alat bantu

\begin{tabular}{|c|c|c|c|}
\hline Alternatif & Pn & Biaya & Vn \\
\hline I (Awal) & 18 & $\operatorname{Rp~} 156.700$ & 1 \\
\hline II & 33 & $\operatorname{Rp~291.200~}$ & 0,99 \\
\hline III & 31 & $\operatorname{Rp~220.900}$ & 1,22 \\
\hline IV & 50 & $\operatorname{Rp~332.300~}$ & 1,31 \\
\hline
\end{tabular}

Dengan demikian, maka pada tahap presentasi ini, alternatif yang dipilih dan menjadi alternatif yang akan dipresentasikan pada alat bantu pen- 
gelasan adalah Alternatif IV karena memiliki nilai (value) yang tertinggi yaitu 1,31 .

\section{HASIL DAN PEMBAHASAN}

Pada bab ini akan dilakukan analisis dari hasil pengolahan data yang telah dikumpulkan dan diolah pada bab sebelumnya. Analisis dari hasil pengolahan data tersebut diuraikan dalam sub bab di bawah ini

\section{Analisa Rancangan Alat}

Dalam proses pengelasan, spesifikasi alat yang dibuat menyebabkan perubahan pada posisi maupun metode kerja pada saat melakukan pengelasan oleh operator. Dengan adanya rancangan alat bantu ini diharapkan operator bisa memahami dan menerima tata cara kerja yang baru yang lebih ergonomi.

Perbedaan spesifikasi pada alat yang dibuat terjadi pada keseluruhan terhadap fasilitas bantu yang ada saat ini, mulai dari cara pemasangan benda kerja,pengukuran, pengaturan, dan pada saat pengelasan. Untuk bagian pemasangan benda kerja, terjadi perubahan yang semula melibatkan 2 orang untuk fit-up dan pengelasan yang diletakkan dilantai menjadi sebuah meja yang memiliki penjepit dari plat besi siku yang terpasang pada meja dan meja tersebut dapat diputar. Hal ini dikarenakan pemasangan sekaligus pengaturan dengan pera- latan sebelumnya memungkinkan terjadinya pergeseran posisi pada benda kerja. Untuk mengatasi kondisi diatas, maka dilengkapi dengan meja yang dapat berputar agar dalam melakukan proses pengelasan operator tidak perlu berpindah-pindah tempat untuk mengelas pada bidang sisi yang lain yang memerlukan pengelasan selanjutnya.

Berdasarkan análisis, alat las rancangan juga mempunyai keunggulan dibandingkan keadaan sebelumnya, karena desain alat las rancangan mengurangi keluhan dibeberapa segmen tubuh, karena posisi pengelasan dilakukan dengan posisi postur tubuh berdiri.

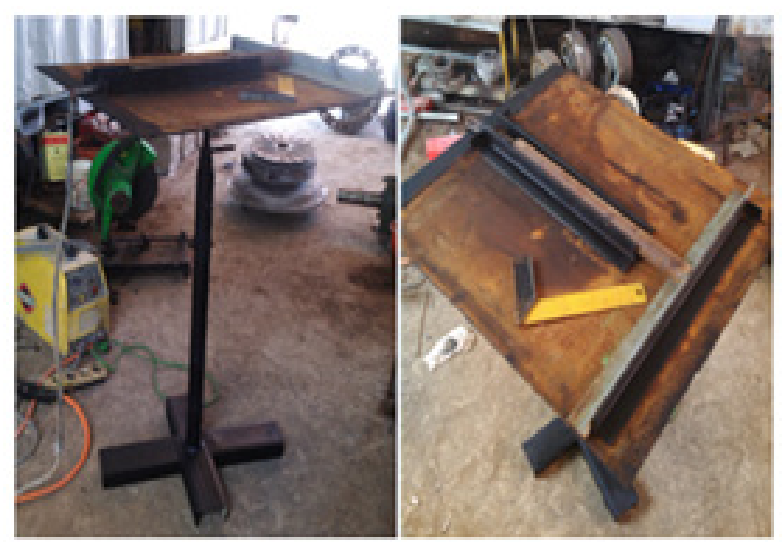

Gambar 5. Desain Alat Bantu Pengelasan Support

Alternatif Terpilih

\section{Analisa Posisi Postur Tubuh Pekerja}

Posisi postur tubuh kerja awal yang dilakukan oleh pekerja saat pengelasan tidak baik. Punggung terlalu membungkuk, kaki dan lutut yang harus menopang tubuh dalam waktu yang cukup lama.

Pada posisi ini operator melakukan pengelasan 
dengan posisi postur tubuh jongkok yang bertumpu pada segmen telapak kaki dan punggung terlalu membungkuk yang diikuti dengan posisi leher yang terlalu kebawah. Hal ini mengakibatkan dirasakan keluhan di bagian pinggang dan dibeberapa segmen tubuh yang terkena dampak dari posisi postur tubuh jongkok tersebut. Berdasarkan analisis yang dilakukan terhadap posisi awal, maka perlu dilakukan perubahan posisi postur tubuh pekerja untuk mengurangi keluhan rasa nyeri dibeberapa segmen tubuh.

Analisis posisi postur tubuh pekerja baru yaitu analisis posisi postur tubuh kerja saat operator melakukan pengelasan menggunakan alat bantu pengelasan yang baru. Posisi postur tubuh pekerja pada saat menggunakan alat bantu las rancangan dapat disesuaikan dengan kenyamanan operator karena sifat alat diposisikan sesuai kebutuhan. Analisis posisi postur tubuh pekerja pada penggunaan alat bantu las yang baru dilakukan dengan mengaplikasikan alat baru terlebih dahulu.

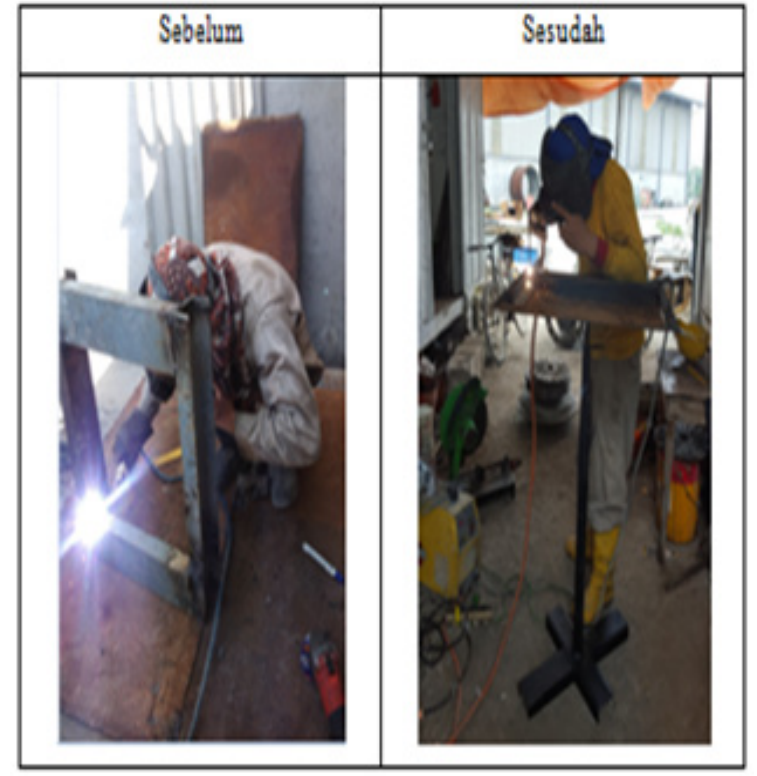

Gambar 6. Perbandingan posisi tubuh pekerja sebelum dan sesudah menggunakan alat bantu di stasiun kerja proses pengelasan

\section{Interpretasi Hasil Penelitian}

Perbaikan postur tubuh kerja di bagian pengelasan dilakukan dengan melihat fasilitas kerja yang digunakan. Peracangan fasilitas kerja secara langsung dapat memperbaiki posisi postur tubuh operator karena operator harus menyesuaikan dengan fasilitas yang digunakan. Berdasarkan aktivitas yang menimbulkan masalah pada tubuh operator pada saat melakukan pengelasan, maka perlu dirancang fasilitas yang mengurangi resiko keluhan kelelahan otot dan rasa nyeri pada saat melakukan aktivitas pengelasan.

Rancangan fasilitas alat bantu pengelasan digunakan untuk memudahkan proses pengelasan terhadap bidang kampuh las tanpa harus memba- 
lik benda kerja, dengan posisi berdiri. Berdasarkan prinsip ergonomi dinyatakan posisi kerja operator berada dalam kondisi yang aman. Berdasarkan aktivitas pengelasan yang dilakukan, berpotensi menimbulkan resiko keluhan. Sedangkan setelah dilakukan perancangan alat bantu pengelasan, dapat mengurangi terjadinya resiko keluhan, karena alat bantu yang dirancang merubah posisi yang semula duduk jongkok dengan punggung membungkuk dirubah menjadi posisi kerja berdiri

\section{KESIMPULAN}

Setelah melakukan studi Ergonomi dan Rekayasa Nilai untuk desain produk alat bantu kerja pengelasan support diperoleh hasil perhitungan jumlah biaya $\operatorname{Rp} 332.300$,- yaitu desain alternatif IV, desain ini mempunyai performance (50) dan value tertinggi $=1,31$.

\section{DAFTAR PUSTAKA}

Ma'arif, Khusnul, 2015. Analisis Postur Kerja Dengan Pendekatan Ergonomi Pada Operator Mesin Las Listrik, Universitas Muhammadiyah Gresik.

Nurmianto, Eko (2005), Ergonomi, Konsep Dasar \& Aplikasinya. Guna Widya. jakarta.

Saaty, 2013, Metode Analisis Hirarki Proses (AHP), viewed 09 November 2015, http://para- digmakaumpedalaman.blogspot.co.id/2012/01/ metode-analisis-hirarki-proses-ahp-dari.html Wignjosoebroto, Sritomo (1995). Ergonomi, Studi Gerak dan Waktu, Guna Widya. Jakarta 